\title{
RI トレーサー法による気中微量水銀の放射化分析法の検討
}

\author{
西村邦夫, 平山 達 \\ 昭和電工(株) 中央研究所 \\ 1968年 9 月 4 日 受理
}

\begin{abstract}
低濃度水銀ガスは過マンガン酸カリウム溶液, アルカリ性次亜臭素酸塩溶液などを捕集液とし, ジチゾン法で分析していた。著者らは, さらに検出限界を下げるため, 放射化分析法を応用するこ とを考光，RIトレーサー技術を用いて，本法の開発を行なった。RIトレーサー法は，水銀のよ5 な低濃度ガスの標識や，分析法の開発手段としてすぐれている。また本研究によって開発された飽 和塩素水を吸収液とした場合, 熱中性子束密度 $1.2 \times 10^{11} n / \mathrm{cm}^{2} \cdot \sec て ゙$ 非破壊分析すると $10^{-3} \mathrm{mg} / \mathrm{m}^{3}$ の濃度まで精度よく定量できた。
\end{abstract}

\section{1. まえがき}

当社, 川崎工場ではソーダ電解法によって水素ガ ス, 塩素, カ性ソーダを製造している。筆者らはラジ オアイソトープ(RI)トレーサー法を利用して, 電解工 程に扣ける淡塩水中への水銀溶出量の測定, 電槽内の 水銀保有量の測定, 水銀収支の検討, 保有量の長期的 変化の測定などの研究1を行なった。これらの研究の 一環として, 製造水素ガス中に混入する微量の水銀量 を測定する必要が生じた。

気体中の水銀の分析は大きく別けて気体中の水銀の 捕集と捕集した水銀の分析の 2 工程である。気体中の 水銀の捕集は，従来臭素ガスを用いる方法，アルカリ 性次亜臭素酸塩溶液 ${ }^{2), 3)}, 0.05 \mathrm{~N}$-過マンガン 酸カリ 溶液( $5 \%$ 硫酸々性) ${ }^{4)}$, 5) などを用いて测定している。 つぎに水銀の分析法では種々の分析法があるが，なか でも, ジチゾン法が最も感度の上い方法と考兄られ, 多くの研究が行なわれてきた。ジチゾン法の検出限界 は $10^{-1} \mu \mathrm{g}$ 程度であるが, 不純物による妨害も多く， 抽出率の変動などによって, 微量の水銀分析には精度 が悪い欠点がある。しかしこの水銀分析に放射化分析 法を応用することによって，さらに精度よく，低濃度 の水銀まで測定できると考えられる。水銀の放射化分 析は, 岩石中の水銀の定量 $\left.{ }^{6)}, 7\right)$, 生物体内の水銀の分 析 $^{8), 9)}$ など多くの分野で応用されている。気体中の水 銀を放射化する場合，まず捕集液として放射化しにく 、物質を使用する必要があるが, 従来の上うな吸収液 では非常に放射化しやすい $\mathrm{K}, \mathrm{Br}$ などを含むため, 不 適当である。したがって, 水銀の捕集液としては, 放 射化しにくい物質から成る液か，または放射化しても 半隇期が短く, 十分な冷却効果が得られる液を開発す る必要がある。著者らは，放射化分析による気体中の
水銀の測定法を確立するために，新なな捕集液の検討， 捕集液の濃縮法の検討, 放射化法の検討などを RIトレ 一サー法，扣よび放射化分析法を用いて実施した。京 たこの結果確立された方法を利用して，実際のサンプ ルについて応用するとともに, 従来行なれれていた， ジチゾン法や検知管法と比較検討した。

RI トレーサー法は, 本研究のごとき, 微量成分の 分析法の解析に役立つのみならず，低濃度ガスの調整 やその収支に有効な手段である。

\section{2. 実験および結果}

本実験で使用した RI は ${ }^{197} \mathrm{Hg}$ である。 ${ }^{197} \mathrm{Hg}$ は石 英アンプルに封入した金属水銀を東京原子力産業研究 所の HTR の炻心找いて，熱中性子束密度 $2.1 \times 10^{12}$ $n / \mathrm{cm}^{2} \cdot \mathrm{sec}$ で放射化し製造し心。金属水銀を放射化し て生成する核種には ${ }^{197} \mathrm{Hg},{ }^{197 \pi} \mathrm{Hg},{ }^{199 m} \mathrm{Hg},{ }^{203} \mathrm{Hg},{ }^{205} \mathrm{Hg}$ などがあるが， ${ }^{197} \mathrm{Hg}$ は半減期 $(65 \mathrm{~h})$ が実験に適し, また $(n, \gamma)$ 反応の放射化断面積が大至く生成量が多い ため,トレーサーに最適である。

\section{$2 \cdot 1$ 標準吸収液の検討}

測定しょうとする $10^{-2} \sim 10^{-4} \mathrm{mg} / \mathrm{m}^{3}$ の濃度の水銀ガ スを捕集するために，標準吸収液として $4 \mathrm{~N}-\mathrm{HCl}(100$ $\mathrm{m} l)+\mathrm{KClO}_{3}(1 \mathrm{~g})$ 溶液を用いて吸収効率を検討した。 従来の方法では低濃度ガスの定量は困難であるため, 検出感度のよいRI トレーサー法を用いた。実験装置 はFig. 1 亿示す。金属水銀は非常に微細化しやすいの で，この性質を利用して，照射水銀を小さな広ロビン の中で振って微粉末を作る。この小水銀粒をガラス棒 を用いて Fig. 1 の水銀ガス発生器に入れて接続する。 この ${ }^{197} \mathrm{Hg}$ で標識された水銀を含む水銀ガス発生器を 恒温水槽中に入れ, 一定温度に保持する。小水銀粒 は，重量の測定は困難であるが，比放射能が高いた 


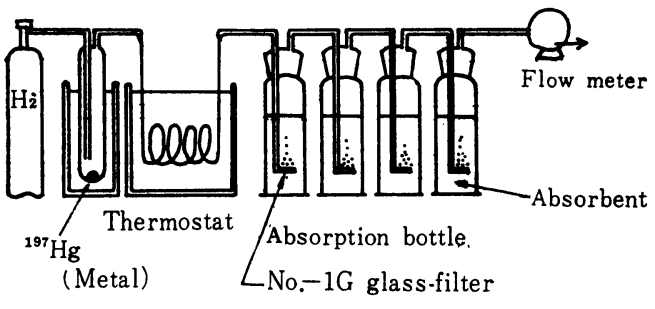

Fig. 1 Experimental apparatus.

め, RI の $\gamma$ 線の計数值によって, 精度よく定量でき る。これは RI 法の大きな利点である。恒温槽内に保 たれた発生器から発生した水銀ガスはボンベから送ら れる $\mathrm{H}_{2}$ ガスで希釈され, ガラスウールを詰めた蛇 管へ送られる。この装置は発生した水銀ガスを均一化 するためとミストをできるだけ少なくするためのも のである。実験条件は水素ガス量 $500 \mathrm{ml} / \mathrm{min}$, 恒温 槽温度 $90^{\circ} \mathrm{C}$, 吸収液量各 $100 \mathrm{ml}$ である。水銀の収支は, 水銀ガス発生器および吸収液中の水銀量を $\mathrm{NaI}(\mathrm{Tl})$ シ ンチレーションカウンターで計測し, 実験前後のカウ ントの差から定量した。発生器内の水銀は発生 器を well タイプのカウンターに直接入れて測定し, 吸収液 は $100 \mathrm{~m} l$ より $4 \mathrm{~m} l$ を分取してポリエチレンカプセル に入れて測定した。測定結果はTable 1 に示す。また 各実験とも吸収ビンは 4 本用い, 直列に接続しておの 扣のの吸収量を測定した。4 本直列に吸収させた結果 は, 最初の吸収ビンですべて吸収されており，2本目 以下では濃度が 4 桁以上低下している。また Table 1 では，吸収量と発生量の収支がよく一致している。し たがって，4 $N-\mathrm{HCl}+\mathrm{KClO}_{3} \mathrm{aq}$ は十分標準溶液とする ことができ， $10^{-3} \mathrm{mg} / \mathrm{m}^{3}$ までの水銀は約 $100 \%$ 吸収で きることが明らかとなった。

Table 1 Absorption factor of low concentration $\mathrm{Hg}$ Gas

(absorbent $4 N-\mathrm{HCl}+\mathrm{KClO}_{3} \mathrm{aq}$ )

\begin{tabular}{c|c|c|c}
\hline Run & $\begin{array}{c}\text { Vapored } \\
\text { mercury (cpm) }\end{array}$ & $\begin{array}{c}\text { Absorbed } \\
\text { mercury (cpm) }\end{array}$ & $\begin{array}{c}\text { Absorption } \\
\text { factor(\%) }\end{array}$ \\
\hline 1 & $4.57 \times 10^{5}$ & $4.63 \times 10^{5}$ & 101 \\
2 & $7.63 \times 10^{5}$ & $7.53 \times 10^{5}$ & 98.8 \\
3 & $2.85 \times 10^{5}$ & $2.90 \times 10^{5}$ & 102 \\
4 & $1.90 \times 10^{5}$ & $1.88 \times 10^{5}$ & 98.9 \\
\hline
\end{tabular}

$2 \cdot 2$ 標識ガスの調製およびミストの検討

Fig. 1 に示す実験では, 水銀が気化するに従って, 表面積が変化し，定常的な濃度のガスを標識できない ことが考えられる。そこでFig. 2 のような装置を作製 して多量の標識水銀にガスを通して定常的低濃度ガス

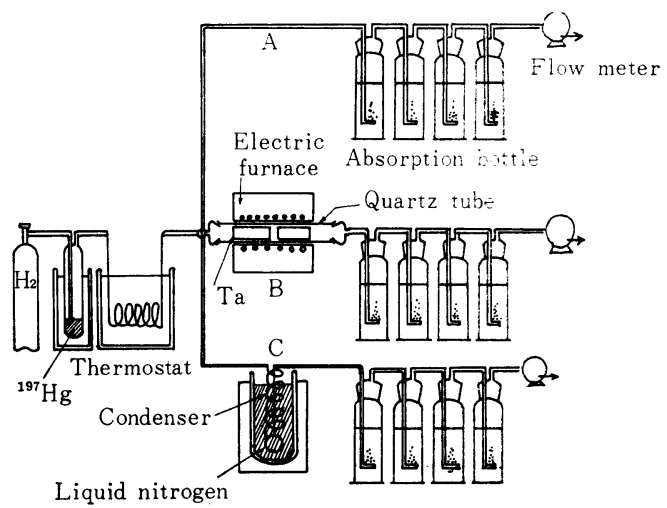

Fig. 2 Experimental apparatus.

を調製した。まず，標識ガスが定常的に調製されてい るか否かを確認するために, $4 \mathrm{~N}-\mathrm{HCl}+\mathrm{KClO}_{3} \mathrm{aq}$ の吸 収液を用いて吸収実験を行なった。吸収実験はFig. 2 のAに示すように, 吸収ビン 4 本を直列に接続し, 吸 収量を求めた。実験条件などは $2 \cdot 1$ の場合と同様であ る。

本法は気液平衡を利用して低濃度の水銀ガスを調製 しているため, 水銀の気化と同時に, 水銀のミストが 生成する拉それがある。もし，、ストが生成すると，吸 収されずに通過する確率 ${ }^{10}$ が多くなり正確な吸収率の 測定が困難となるため, ミストの存在を確認する必要 がある。ミストを確認する方法"11には，1）ミストを破 壊する方法，2）限外顕微鏡で観察する方法，などがあ る。そこでFig. 2 のBに示すようなミスト破壊実験す 行なった。調製した低濃度水銀ガスを電気炉で $650{ }^{\circ} \mathrm{C}$ に加熱した破壊系に通じ，最後に完全にガス化した水 銀を $4 \mathrm{~N}-\mathrm{HCl}+\mathrm{KClO}_{3} \mathrm{aq}$ で吸収する。もし，ミストが 存在すれば炉内で加熱され，ミストが破壊され，ガス 化するため, 水銀の吸収量が多くなる。ミストの破壊 は，石英管内に $\mathrm{Ta}$ 板 $(10 \mathrm{~cm} \times 10 \mathrm{~cm}) 2$ 枚を学》 て，ガスの通過する経路に入れ，外部から650 $\mathrm{C}$ 加 熱した。水銀は他の金属とアマルガムを生成しやすい が，Taは高温に扣いても，ほとんど生成しない12)。 しかし，取り扱う水銀量がきわめて微量であるのに対 して，Ta 量が多いため，アマルガムの影響が出るこ とも考ええられた。この影響をのぞくために，実験後 に Ta 板を $1 \mathrm{~N}-\mathrm{HNO}_{3} \mathrm{aq}$ で洗浄し, 洗浄液中の水銀 濃度も測定した。また Ta板は高温水素気流中では著 しく括かされるので, この実験のみは, $\mathrm{N}_{2}$ ガス気流 で実験した。ミストの破壊実験は, 実験と同時にオリ ンパス製の限外顕微鏡によって確認子行なった。本限 外顕微鏡の測定限界は $0.1 \mu$ である。 
Table 2 Comparison of vapored mercury

\begin{tabular}{|c|c|c|c|c|}
\hline \multirow{2}{*}{ Experiment } & \multirow{2}{*}{$\begin{array}{l}\text { Weight of condenced } \\
\text { mercury } \\
\qquad(\mu \mathrm{g})\end{array}$} & \multicolumn{2}{|c|}{ Weight of absorbed mercury $(\mu \mathrm{g})$} & \multirow{2}{*}{$\begin{array}{c}\text { Total weight } \\
(\mu \mathrm{g})\end{array}$} \\
\hline & & 1st absorption bottle & 2nd absorption bottle & \\
\hline A & - & 61.3 & - & 61.3 \\
\hline $\mathrm{B}$ & - & 60.8 & - & 60.8 \\
\hline $\mathrm{C}$ & 60.9 & 0.01 & - & 60.9 \\
\hline
\end{tabular}

また，発生する水銀が，ガスの場合は液体窒素で冷 却すれば，すべて凝縮する。そこで Fig. 2 のCに示 すように，低濃度ガスを液体窒素で冷却したコンデン サーに通し，凝縮させ，さらに $4 \mathrm{~N}-\mathrm{HCl}+\mathrm{KClO}_{3} \mathrm{aq} に$ 吸収させた。コンデンサーは実験後 $10 \mathrm{ml}$ の conc $\mathrm{HNO}_{3}$ で溶解洗浄し洗液中の水銀量を定量した。測定 結果はTable 2 に示す。Table 2 より，3つの実験は 連続的に実施したにもかかわらず，ほぼ同一の值が得 られた。したがって水銀のガス化量は注ぼ一定してい ることぶ証明された。またミスト実験の結果，ミスト を破壊した場合と，しない場合の值がほぼ一致した。 このことは，本実験の場合，水銀ガス中にはミストが ほとんえ゙存在しなかったことをしめす。同時に限外顕 微鏡で観測した結果でもミストの存在は確認されなか った。本実験においても，2 本目以後の吸収ビンには カウントは計数されなかった。

\section{$2 \cdot 3$ 低濃度ガスの吸収率の測定}

$2 \cdot 1$ 年よび $2 \cdot 2$ の実験では水銀濃度が $1 \sim 0.1 \mathrm{mg} / \mathrm{m}^{3}$ の範囲で測定したるのである。したがって,0.1〜0.001 $\mathrm{mg} / \mathrm{m}^{3}$ の低濃度での吸収率は, 正確には不明である。 筆者は，2・2 の方法で得られた微量水銀ガスを 2 段, 3 段に希釈し, $4 \mathrm{~N}-\mathrm{HCl}+\mathrm{KClO}_{3} \mathrm{aq}$ を吸収液として吸 収実験を行なった。実験結果はTable 3 に示す。 Table 3 の $10^{-3} \mathrm{mg} / \mathrm{m}^{3}$ の濃度の測定結果は $10^{-1} \sim 10^{-2}$ $\mathrm{mg} / \mathrm{m}^{3}$ の範囲の結果に比べ誤差が大きい。これはト レーサーとして使用した水銀の比放射能が低く計測誤 差が大きく(土10\%)なるためである。したがって $10^{-3}$ $\mathrm{mg} / \mathrm{m}^{3}$ の範囲のバラツキが計測誤差範囲にはいると 考えれば，本吸収液の吸収率は約100\%である。2・1の 実験結果とともに考虑すると塩素酸カリウム溶液は有 効な吸収液であり，標準吸収液として用いることがで きる。しかし，この溶液中にはK $\left(3.19 \times 10^{-1} \mathrm{~g}\right)$ が含ま れているため, 放射化すると多量の ${ }^{42} \mathrm{~K}(\gamma-1.51 \mathrm{MeV})$

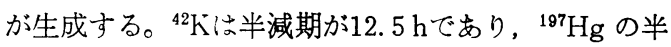
減期 $65 \mathrm{~h}$ 亿近いため，低濃度の水銀分析には適当でな い。そこで水銀の吸収液としては放射化しにくい成分
の液を開発する必要がある。筆者らは，まず，水銀と 反応性にとむ, 飽和塩素水, conc $\mathrm{HNO}_{3} \mathrm{aq}$ などを考 え, 吸収率の测定を試みた。飽和塩素水は $1 l$ の蒸留 水にガラスフィルター (No.-1G) を通して塩素ガスを 15分間バブリングさせ, 過飽和となった液を使用した。 吸収ビンは各濃度について $2 \sim 4$ 本直列に接続し, 吸 収液を $100 \mathrm{ml}$ ずつ入れ, 最後に水銀の口スを確認する ために，4 $\mathrm{N}$ - $\mathrm{HCl}+\mathrm{KClO}_{3} \mathrm{aq}$ の吸収液を接続した。 実験時間は 1 時間, 実験条件は $2 \cdot 1$ と同様である。

Table 3 Absorption factor of low concentration $\mathrm{Hg}$ gas (absorbent: $4 \mathrm{NHCl}+\mathrm{KClO}_{3}$ )

\begin{tabular}{|c|c|}
\hline $\begin{array}{l}\text { Concentration of mercury } \\
\qquad\left(\mathrm{mg} / \mathrm{m}^{3}\right)\end{array}$ & $\begin{array}{l}\text { Absorption } \\
\text { factor }(\%)\end{array}$ \\
\hline 3. $27 \times 10^{-1}$ & 100 \\
\hline $1.13 \times 10^{-1}$ & 99.8 \\
\hline $5.09 \times 10^{-2}$ & 99.9 \\
\hline 3. $44 \times 10^{-2}$ & 101 \\
\hline $6.15 \times 10^{-3}$ & 105 \\
\hline 2. $78 \times 10^{-3}$ & 96.2 \\
\hline
\end{tabular}

飽和塩素水の吸収率測定結果は Table 4 に, 濃硝酸 の測定結果は Table 5 に示す。Table 4,5 のデータ を比較すると, 飽和塩素水の吸収率は 100\% 得られて いるが，濃硝酸の吸収率は36\%以下である。しかも，

Table 4 Absorption factor of low concentration $\mathrm{Hg}$ gas

(absorbent: saturated sol. of $\mathrm{Cl}_{2}$ )

\begin{tabular}{|c|c|}
\hline $\begin{array}{r}\text { Concentration of mercury } \\
\left(\mathrm{mg} / \mathrm{m}^{3}\right)\end{array}$ & $\begin{array}{l}\text { Absorption } \\
\text { factor }(\%)\end{array}$ \\
\hline 9. $78 \times 10^{-1}$ & 99.8 \\
\hline $2.88 \times 10^{-1}$ & 102 \\
\hline $5.00 \times 10^{-2}$ & 101 \\
\hline 4. $12 \times 10^{-2}$ & 101 \\
\hline 5. $03 \times 10^{-3}$ & 104 \\
\hline 1. $89 \times 10^{-3}$ & 106 \\
\hline
\end{tabular}


Table 5 Absorption factor of low concentration $\mathrm{Hg}$ gas (absorbent: conc $\mathrm{HNO}_{3}$ )

\begin{tabular}{|c|c|}
\hline $\begin{array}{r}\text { Concentration of mercury } \\
\qquad\left(\mathrm{mg} / \mathrm{m}^{3}\right)\end{array}$ & $\begin{array}{l}\text { Absorption } \\
\text { factor }(\%)\end{array}$ \\
\hline $2.93 \times 10^{-1}$ & 33.4 \\
\hline 4. $99 \times 10^{-2}$ & 36.4 \\
\hline $3.07 \times 10^{-2}$ & 19.8 \\
\hline $2.93 \times 10^{-3}$ & 2.1 \\
\hline $2.88 \times 10^{-3}$ & 5.8 \\
\hline
\end{tabular}

塩素水の場合は, 塩素酸カリウム溶液の場合とよく一 致し，2本目，3本目にはほとんど検出されなかった が，濃硝酸の吸収液では 2 本目，3本目にもほとんど 同一量が吸収されていた。したがって濃硝酸の場合は 3 本を加えたものとして算出した。この結果から，今 後は水銀の吸収液として飽和塩素水を対象として研究 を進める。

\section{$2 \cdot 4$ 吸収時間}

吸収液に飽和塩素水を用いて吸収させた場合，ガス を連続的に通すため，吸収している間に気液平衡によ って塩素ガスが放出される。したがって塩素ガスの濃 度が低下し，水銀の吸収率に影響を与えることが考え られるので, 試料の採取時間と吸収率の関係を測定し た。実験濃度は $0.1 \mathrm{mg} / \mathrm{m}^{3}$ の低濃度ガス, 吸収系は飽 和塩素水の吸収 ビン 2 本と $4 \mathrm{~N}-\mathrm{HCl}+\mathrm{KClO}_{3} \mathrm{aq}$ の吸 収ビン 1 本を直列に接続したものである。通気ガス量 は500 ml/minである。実験結果は吸収時間を横軸に, 水銀の吸収量を計数率で示した值を縦軸にとり， Fig. 3 に示した。本実験においては30分〜 1 時間30分の範 囲では，1本目の吸収液のみにカウントが計数され， 2 本目以降にはほとんど検出されなかった。2 時間吸 収のサンプルは，1 本目に $98.3 \% ， 2$ 本目 $1.7 \%$ 吸収 された。

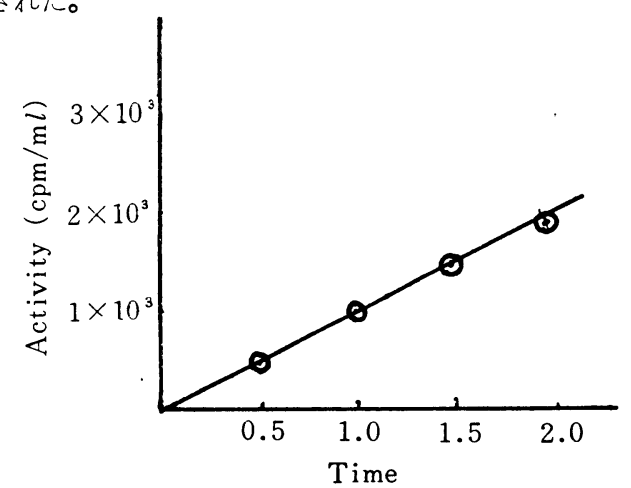

Fig. 3 Relationship between absorption time and activitiy of mercury.
この結果，吸収時間は1.5時間までは $100 \%$ 吸収され るが，2 時間以降は誤差が多くなる。しかし，放射化 分析の精度からすれば，2 時間でも十分である。また 吸収の途中で塩素ガスを補充してやるとさらに長時間 効率よく吸収できるものと考えられる。

\section{$2 \cdot 5$ 吸収液の濃縮}

吸収した水銀捕集液はつぎに，放射化分析するため に, 照射試料に調製する。照射用のアンプルの内容積 は10〜 $15 \mathrm{ml}$ であるので, 捕集液を濃縮する必要があ る。塩素水中の水銀は塩化物として存在すると, 塩化 物は蒸気圧が高いために, 濃縮過程で, 水銀の損失が 生ずることが考えられる。したがって濃縮過程におけ る水銀の損失を検討するとともに，損失を少なくする ために, conc $\mathrm{HNO}_{3}$ aq を添加する方法を検討した。

まず，吸収調製した低濃度水銀溶液から一定量を分 取し, 溶液中の水銀量を, 計数率で測定した。その溶 液より $100 \mathrm{ml}$ を分取し，95〜97 Cの湯煎を用いて 2 時間以上時間をかけて, 徐々に蒸発濃縮 して $8 \mathrm{ml}$ と する。液の濃縮後, 濃縮液を定容し, 液中の水銀量を 計数し，濃縮前後の水銀量を比較した。

蒸発濃縮による損失は初期の水銀濃度によって異な る可能性があるので, 初期濃度を $0.1 \mu \mathrm{g} / 100 \mathrm{ml} \sim 100$ $\mu \mathrm{g} / 100 \mathrm{ml}$ まで 4 種類にわけて実験した。この結果, 飽和塩素水のまま濃縮した場合, 残存水銀量は, 初期 の水銀量の 80 〜 $90 \%$ であり，20\%近く損失がある。 筆者らは, この水銀の損失量を少なくするために, conc $\mathrm{HNO}_{3}$ aq を一定量試料水に添加し, 濃縮する方法を 検討した。実験は, $100 \mathrm{ml}$ の試料水に各 $1,3,6,8 \mathrm{ml}$ を添加し, 前記と同様の方法で濃縮し, 测定試料を調 製し, 計数する。実験結果は Fig. 4 に示す。Fig. 4 よ $\eta$, 吸収液 $100 \mathrm{ml}$ に対し, $4 \mathrm{ml}$ 以上の硝酸を加えて

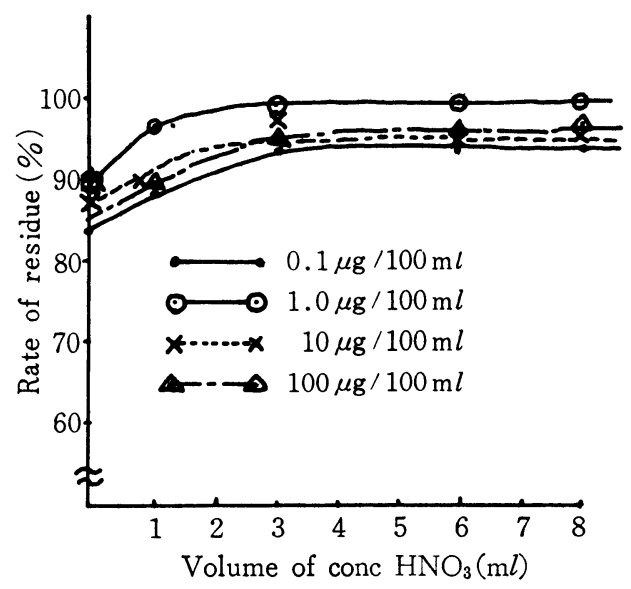

Fig. 4 Rate of residue of mercury. 
濃縮すると，濃縮時の水銀損失は $5 \%$ 以下であり，ま た $4 \mathrm{~m} l$ 以上加えて为効果がないことが証明された。 また, $0.1 \mu \mathrm{g} / 100 \mathrm{ml}$ の濃度までは, $1 / 10$ 程度まで濃縮し ても水銀は濃度に関係なく, ほとんど回収されること が確認された。Fig. 4 より水銀の損失は硝酸を添加し ても，5\%程度のバラツキがあるが，放射化分析法の 精度から考えれば, この程度の誤差は許容できるもの と考えられる。

$2 \cdot 6$ 照射用カプセルへの水銀の吸着および溶出

照射試料は放射化するために照射カプセルに封入す る。従来, 放射化用のカプセルには, ポリエチレンや 石英製のカプセルが使用されているが，水銀は吸着性 が強いために，これらのカプセルが，水銀の放射化 分析に適するか否かを検討する必要がある。実験はま ず塩化水銀の水溶液 $(20 \mu \mathrm{g} / 5 \mathrm{ml})$ を拉の拉のの照射力 プセルに封入し, 前記の HTR 炉心(flux $2.0 \times 10^{12} n$ / $\mathrm{cm}^{2} \cdot \mathrm{sec}$ ) で 5 時間照射する。照射後, 各カプセルから 封入液を取り出しカプセル内に吸着した水銀量を測定 する。つぎに, 水銀を吸着したカプセル内に, 1 回あ たり $5 \mathrm{ml}$ の conc $\mathrm{HNO}_{3}$ 溶液を入れよく洗浄する。 洗液は同様にして水銀量を測定し溶出量および吸着量 を求めた。この操作を 5 回くり返し, 同様に测定し た。実験結果は Table 6 に示す。

Table 6 Rate of elution of mercury from capsule (\%)

\begin{tabular}{l|c|c}
\hline Capsule & $\begin{array}{c}\text { polyethylene } \\
\text { capsule (\%) }\end{array}$ & $\begin{array}{c}\text { quartz } \\
\text { capsule(\%) }\end{array}$ \\
\hline Irradiated solu. & 29.4 & 96.4 \\
1st wash liquid & 21.3 & 2.6 \\
2nd "I & 10.3 & 0.3 \\
3rd "I & 3.2 & 0.2 \\
4th "I & 2.3 & 0.2 \\
5th " & 1.7 & $0.1<$ \\
rate of residue & 31.8 & 0.3 \\
\hline
\end{tabular}

Table 6 よりポリエチレンカプセルに対する水銀吸 着量は多く, 硝酸で 5 回洗浄してる31.8\%の水銀がポ リエチレンに残る。ところが石英カプセルでは, 吸着 量が少なく, 照射した原液中に $96.4 \%$ 水銀が存在し, 1 回洗浄すれば99\%回収されることが明らかとなっ た。したがって, 水銀溶液の放射化には, 石英カプセ ルが最子適して扣り, 硝酸溶液で $2 \sim 3$ 回洗浄すれ ば，100\%近くの水銀が回収されることが証明された。 $2 \cdot 7$ 放射化分析

石英製カプセルに封入した分析試料はポリエチレン 袋に三重に包装する。標準試料としては Johnson
Matthey 製の金属水銀を硝酸に溶解し，所定濃度に調 製したものを用いた。分析試料は標準試料と並べ，照 射棚 (熱中性子束密度 $1.2 \times 10^{11} n / \mathrm{cm}^{2} \cdot \mathrm{sec}$ ) て 5 時間放 射化した。照射済又の試料は 100 時間冷却し, 不純物 として生成する短寿命核種を十分减衰させた。測定 は, 水銀の $(n, \gamma)$ 反応によって生成する ${ }^{197 m} \mathrm{Hg},{ }^{197} \mathrm{Hg}$, ${ }^{199 m} \mathrm{Hg},{ }^{203} \mathrm{Hg},{ }^{205} \mathrm{Hg}$, のうち, 生成量が多く, 半減期 が実験に適している ${ }^{197} \mathrm{Hg}$ で行なった。定量は, ${ }^{197} \mathrm{Hg}$ の放出する $0.077 \mathrm{MeV}$ の $\gamma$ 線执よびX線 $(0.068 \mathrm{MeV}$ -Au）による光電ピークの積分值を標準試料のそれと 比較して行なった。

以上述べてきた方法を現場のサンブルに応用するこ とを考え，川崎工場に括いてサンプリングした。現場 の試料は, ソーダ電解工場の水素精製工程上り送り出 される水素輸送パイプから分枝させ，吸収させた。吸 収液は飽和塩素水, および $\mathrm{HNO}_{3} \mathrm{aq}$ を用い吸収液別

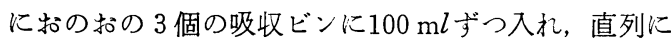
連結した。飽和塩素水と $\mathrm{HNO}_{3} \mathrm{aq}$ は同時に別々にサ ンプリングし比較検討した。通気ガス量は $500 \mathrm{ml} / \mathrm{min}$ の割合で 2 時間吸収させた。吸収捕集した陚料を $8 \mathrm{ml}$ まで濃縮し，照射カプセルに封入する。照射サンプル は前記の HTR で放射化し，前記の方法で非破壊分析 した。

放射化分析を行なうと同時に，ジチゾン法や検知管 法の分析を試み，放射化分析法と比較した。測定結果 は Table 7 に示す。

Table 7 より, 従来検知管法やジチゾン法で不可能 であった低濃度ガスの分析も，放射化分析を利用する ことによって十分测定できるようになった。また，放 射化分析は，吸収率の悪かった硝酸溶液について子実 施したが，結果は，飽和塩素水に比較して著しく悪 く, RI トレーサー法による吸収率の测定結果とよく 一致した。

Table 7 Determination results of mercury in gas

\begin{tabular}{c|c|c|c|c}
\hline Method & $\begin{array}{c}\text { Gas detector } \\
\text { tube method }\end{array}$ & $\begin{array}{l}\text { Dithi- } \\
\text { zone } \\
\text { method }\end{array}$ & \multicolumn{2}{|c}{$\begin{array}{c}\text { Activation } \\
\text { analysis }\end{array}$} \\
\hline Absor- \\
bent & $\begin{array}{c}\text { Saturated } \\
\text { solution of } \\
\mathrm{Cl}_{2}\end{array}$ & $\prime \prime$ & $\prime \prime$ & $\begin{array}{c}\text { conc } \\
\mathrm{HNO}_{3}\end{array}$ \\
\hline 1 & - & 0.01 & $2.5 \times 10^{-2}$ & $7.8 \times 10^{-3}$ \\
2 & - & none & $4.6 \times 10^{-3}$ & $8 \times 10^{-4}$ \\
3 & none & $<0.01$ & $2.9 \times 10^{-3}$ & $6 \times 10^{-4}$ \\
4 & - & none & $1.1 \times 10^{-2}$ & $3 \times 10^{-3}$ \\
5 & none & 0.01 & $2.8 \times 10^{-2}$ & $1.5 \times 10^{-3}$ \\
6 & - & $<0.01$ & $2.6 \times 10^{-3}$ & $7 \times 10^{-4}$ \\
\hline
\end{tabular}




\section{3. 考 察}

RI トレーサー法は本研究のような低濃度ガスの標 識に適し，分析法の解析などに大いに利用できる。水 銀のように蒸気圧を利用して低濃度のガスの標識を行 なえる物質には効果がある。

本分析法で問題となる誤差の大きなものは, fluxの バラツキ, 試料処理のさいの誤差, 妨害核種の影響な ぞがある。flux のバラッキは $5 \%$ 以下であり, 試料処 理による誤差は前記の実験から考えて最大 $5 \%$ 程度で ある。標的核種の ${ }^{196} \mathrm{Hg}$ は放射化断面積が大きく(880 barns), 吸収断面積も大きい。したがって試料の自己 遮へいる考光られるが, 本研究のような低濃度の水銀 の場合は，ほとんど影響がない。測定した ${ }^{197} \mathrm{Hg}$ の放 出する約70 keV の光電ピークは土ネルギーが低いた め, 試料による自己吸収を考慮する必要がある。しか し試料は水溶液であるため，比較的 $\gamma$ 線の吸収率が小 さく，また標準試料と同一の計数効率で测定するの で，吸収率の影響は無視できる。

本測定は HTR の照射棚 $\left(1.2 \times 10^{11} n / \mathrm{cm}^{2} \cdot \mathrm{sec}\right)$ で放 射化し，非破壊分析法で分析した。しかし，さらに中 性子密度の高い炉心 $\left(2.2 \times 10^{12} \mathrm{n} / \mathrm{cm}^{2} \cdot \mathrm{sec}\right)$ で放射化し， 破壊分析学用いることによって，ょり精度よく低濃度 $\left(10^{-5} \mathrm{mg} / \mathrm{m}^{3}\right)$ の測定が可能であろう。

\section{付 記}

本研究の実施にさいし, 東京原子力産業研究所の大
内淳弘氏にご協力いただいたことを深く感謝いたしま す。

\section{文献}

1）西村, 大柴, 平山：第 8 回日本アイソトープ会 議報文集，B/(3)-8，285（1967）

2) Buckell, M., Hunter, D., Milton, R. and Perry, K.M.A.: Brit. J. Industr. Med., 3, 55 (1946)

3) Milton and Duffield, W.D.: Analyst, 72,11 (1947)

4) Buckell, M.: Brit. J. Industr. Med., 8,181 (1951)

5) Massmann, W., and Sprecher, D.: Arch. Toxikol., 16, 264 (1957)

6) Morris, D.F.C. and Killick, P.A.: Talanta, 11, 781 (1964)

7) Ehmann, W.D. and Huizenga, J.R.: Geochimica et Cosmochimica Acta, 17, 125 (1959)

8) Hamilton Smith: Anal. Chem., 35, (6) 635 (1963)

9) 星野, 丹沢, 寺尾, 浮田, 大内: 衛生化学, 12, 94. (1966)

10) Hendrickson, E.A. : Air Pollution, Vol. 1, p. 389 Academic Press (1962)

11）今井：高圧ガス協会誌, 26, (1)21（1962）

12) Hansen Max: Constitution of Binary Alloys, Second Ed., McGraw-Hill Book Co., 840 (1958)

\title{
Abstract
}

\section{Investigation of Activation Analysis of Trace Mercury in Gas by Radioisotope Tracer Method}

\author{
Kunio Nishimura and Tohru Hirayama \\ Central Research Laboratory, Showa Denko KK \\ Tamagawa-2, Ota-ku, Tokyo
}

The most of chemical methods for determination of mercury in gas camprises of collection of mercury from large volume of gas and of estimation of the amount of mercury collected.

Dithizone methoa seems to have many merits for determination of small amount of mercury, but it is interfered by many kinds of impurities. Neutron activation analysis is suitable to the determination of mercury of low concentration because of the high sensitivity. For the development of the method of determination, the radioisotope tracer technique and 
activation analysis are very useful. Thus, we established the following method and analytical results were compared to those by dithizone method and gas detector tube method. In this method absorbent is saturated chlorine solution and absorption time is 2 hrs. After absorption, $4 \mathrm{ml}$ of conc $\mathrm{HNO}_{3} \mathrm{aq}$ is added to the absorbent, and the mixture is concentrated to $8 \mathrm{ml}$, then it is sealed in the quartz capsule. Irradiation is carried out in HTR with neutron flux of $1.2 \times 10^{11} \mathrm{n} / \mathrm{cm}^{2} \cdot \mathrm{sec}$ for $5 \mathrm{hrs}$. After cooling for $100 \mathrm{hrs.,} \mathrm{samples} \mathrm{are} \mathrm{taken} \mathrm{out} \mathrm{from}$ capsule and determined by the non-destructive method. The sensitivity of this method is $10^{-3} \mathrm{mg} / \mathrm{m}^{3}$. However the sensitivity can be improved by use of irradiation with higher neutron fluxes and destructive methods.

(Received September 4,1968) 